\title{
Analysis of Merit System in the Open Promotion of High Leadership Positions for Women in the Ministry of Home Affairs
}

\author{
Tian Nirwana ${ }^{1}$, Eko Prasojo ${ }^{2}$ \\ 1,2 Universitas Indonesia, Mochtar Building 3rd Floor, Jl. Pegangsaan Timur No.16, Cikini, Central Jakarta, Indonesia \\ Corresponding Author: tian.nirwana@gmail.com \\ doi) https://doi.org/10.18196/jgpp.v8i3.12208
}

Article Info

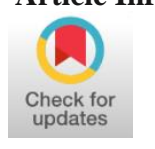

Article History; Received: 2021-05-15 Revised: 2021-07-26 Accepted: 2021-09-04

\begin{abstract}
This research aims to analyze the application of the merit system in the open promotion of High Leadership Positions (JPT) for women and find out the factors that influence women's vertical mobility in the bureaucracy. This research was conducted at the Ministry of Home Affairs using a postpositivist research approach and qualitative data collection technique. The results showed that filling in the JPT at the Ministry of Home Affairs has not been based on a succession plan, and there is a Pelaksana Tugas (Plt) JPT with a term exceeding the applicable provisions. In addition, there were differences in administrative requirements for selection vacancies with relevant regulations. The track record tracking process was only carried out through curriculum evaluation and monitoring and evaluation of High-ranking Officials (PPT) performance appraisals only based on Employee Performance Target (SKP) every year. Women's interest in registering for selection tends to be slight, and incomplete facilities support women's productivity. The results also showed differences from previous research. The merit system policy in this study refers to the Regulation of the Minister of Administrative Reform and Bureaucratic Reform (Permenpanrb) Number 15 of 2019. Besides, it also proves the inaccuracy of The Theory of Organizational Barries, Self-imposed Barriers, and Gender Role Congruity.
\end{abstract}

Keyword: Civil Service; Merit System; Open Selection; Glass Ceiling.

\section{INTRODUCTION}

Bureaucratic reform in Indonesia is currently included in the third period of the Grand Design Bureaucratic Reform (GDRB), the year 2020-2024, which has good and clean governance with bureaucratic reform targets, namely a clean, accountable, and capable bureaucracy, and excellent public services. Based on the report evaluating the implementation of bureaucratic reform in 2019, the Ministry of Home Affairs obtained a bureaucratic reform index value of 75.43 with a BB (good) rating. Structuring the State Civil Apparatus (ASN) management system is the lever component with the most significant assessment weight in the 2018-2019 Ministry of Home Affairs Bureaucratic Reform Index, one of which is the merit system index. In 2018, the Ministry of Home Affairs obtained an assessment of the level of application of the merit system of 297, which showed good results. These results illustrate that the Ministry of Home Affairs has implemented a merit system, but something needs improvement.

Structuring the Human Resources of The Apparatus is one area of change in bureaucratic reform that is critical because the state apparatus or civil servants are an essential asset in the development process of a country and towards the development of human capital. (Prasojo, 2009) said that the problems of the state apparatus were seen from internal problems in the personnel system, which included recruitment, remuneration and rewards, performance measurement, promotion, and supervision, as well as external issues, the co-optation of political parties against 
civil servants. The problems can be solved through bureaucratic reform efforts in personnel embodied in the (Undang-Undang Nomor 5 Tahun 2014 Tentang Aparatur Sipil Negara, 2014) to realize professional, integrity, and highly competitive ASN by implementing ASN management based on a merit system by emphasizing competence and not patronage (Prasodjo \& Rudita, 2014).

One of the fundamental changes in the merit system in the ASN Law is the change in approach from a closed career system to an open career system, such as the promotion of civil servants through an open selection mechanism in filling out the JPT. The promotion of civil servants, especially women, can be seen based on the number of women who occupy JPT in the bureaucracy. This number tends to decrease even though the number of female civil servants has increased. In 2019, the number of civil servants in Indonesia was 51.51\%, increasing compared to the previous two years, $45.76 \%$ in 2017 and $50.51 \%$ in 2018 . This number was more than men, $49.49 \%$ in 2018 and $48.49 \%$ in 2019 (Table 1).

Table. 1 Number of Civil Servants in Indonesia 2015-2019

\begin{tabular}{cccccc}
\hline \multirow{2}{*}{ Year } & \multicolumn{3}{c}{ Men } & \multicolumn{3}{c}{ Women } & Total \\
\cline { 2 - 5 } & Amount & $\%$ & Amount & $\%$ & \\
$\mathbf{2 0 1 5}$ & 2.354 .226 & 51,25 & 2.239 .278 & 48,75 & 4.593 .504 \\
$\mathbf{2 0 1 6}$ & 2.217 .486 & 50,69 & 2.156 .855 & 49,31 & 4.374 .341 \\
$\mathbf{2 0 1 7}$ & 2.326 .487 & 54,24 & 1.962 .909 & 45,76 & 4.289 .396 \\
$\mathbf{2 0 1 8}$ & 2.071 .310 & 49,49 & 2.114 .193 & 50,51 & 4.185 .503 \\
$\mathbf{2 0 1 9}$ & 2.031 .294 & 48,49 & 2.157 .827 & 51,51 & 4.189 .121 \\
\hline
\end{tabular}

Source: State Civil Service Agency, 2019

Although female civil servants are more female than men, female civil servants decrease when entering structural positions, especially at JPT Echelon I and II, $0.02 \%$ and $0.56 \%$, respectively. Based on the type of position, 445,754 civil servants occupy structural positions, but only 149,598 are female civil servants. Civil servants occupying the most structural positions are Echelon IV, and the least are Echelon I (Table 2).

Table 2. Number of Civil Servants by Structural Position and Gender as of June 2019

\begin{tabular}{lcrrrrr}
\hline Structural & \multicolumn{2}{c}{ Men } & \multicolumn{3}{c}{ Women } & \multicolumn{2}{c}{ Total } & $\%$ \\
\cline { 2 - 4 } Position & Amount & $\%$ & Amount & $\%$ & & \\
Echelon I & 480 & 0,11 & 95 & 0,02 & 575 & 0,13 \\
Echelon II & 16.896 & 3,79 & 2.567 & 0,58 & 19.463 & 4,37 \\
Echelon III & 75.309 & 16,89 & 23.349 & 5,24 & 98.658 & 22,13 \\
Echelon IV & 203.471 & 45,65 & 123.587 & 27,72 & 327.058 & 73,37 \\
Total & 296.156 & 66,44 & 149.598 & 33,56 & 445.754 & 100 \\
\hline S
\end{tabular}

Source: State Civil Service Agency, 2019

The lack of representation of women in the JPT also occurs in the Ministry of Home Affairs. In 2019, the number of civil servants at the Ministry of Home Affairs was 4,930 people consisting of $60.04 \%$ men and $39.96 \%$ women (Table 3 ).

Table.3 Number of Civil Servants in the Ministry of Home Affairs in 2015-2019

\begin{tabular}{lccccc}
\hline Year & \multicolumn{3}{c}{ Men } & \multicolumn{3}{c}{ Women } & Total \\
\cline { 2 - 5 } & Amount & $\%$ & Amount & $\%$ & 4.945 \\
$\mathbf{2 0 1 5}$ & 3.020 & 61,07 & 1.925 & 38,93 & 4.998 \\
$\mathbf{2 0 1 6}$ & 3.038 & 60,78 & 1.960 & 39,22 & 4.942 \\
$\mathbf{2 0 1 7}$ & 2.997 & 60,64 & 1.945 & 39,36 & 4.910 \\
$\mathbf{2 0 1 8}$ & 2.942 & 59,92 & 1.968 & 40,08 & 4.930 \\
$\mathbf{2 0 1 9}$ & 2.960 & 60,04 & 1.970 & 39,96 & \\
\hline
\end{tabular}

Source: State Civil Service Agency, 2019 
As of August 2020, 1,295 civil servants held structural positions, with the highest number of civil servants being Echelon IV and the least being Echelon I. The number of civil servants occupying JPT Echelon II was 4.63\% male and 0.77\% female, whereas Echelon I was $1.39 \%$ male and $0.08 \%$ female (Table 4 ).

Table.4 Number of Civil Servants at the Ministry of Home Affairs by Structural Position and Gender as of 31 August 2020

\begin{tabular}{|c|c|c|c|c|c|c|}
\hline \multirow{2}{*}{$\begin{array}{c}\text { Structural } \\
\text { Position }\end{array}$} & \multicolumn{2}{|c|}{ Men } & \multicolumn{2}{|c|}{ Women } & \multirow[t]{2}{*}{ Total } & \multirow[t]{2}{*}{$\%$} \\
\hline & Amount & $\%$ & Amount & $\%$ & & \\
\hline Echelon I & 18 & 1,39 & 1 & 0,08 & 19 & 1,47 \\
\hline Echelon II & 60 & 4,63 & 10 & 0,77 & 70 & 5,40 \\
\hline Echelon III & 235 & 18,15 & 94 & 7,26 & 329 & 25,41 \\
\hline Echelon IV & 554 & 42,78 & 323 & 24,94 & 877 & 67,72 \\
\hline Total & 867 & 66,95 & 428 & 33,05 & 1.295 & 100 \\
\hline
\end{tabular}

Source: Biro Kepegawaian, Kemendagri

Based on the results of the open selection on November 24, 2020, the female JPT Echelon II increased by one person so that the number of female Echelon II officials became 11 people consisting of Kepala Biro Kepegawaian Sekretariat Jenderal, Sekretaris Direktur Jenderal Bina Pembangunan Daerah, Direktur Sinkronisasi Urusan Pemerintahan Daerah IV pada Direktorat Jenderal Bina Pembangunan Daerah, Direktur Evaluasi Perkembangan Desa pada Direktorat Jenderal Bina Pemerintahan Desa, Direktur Fasilitasi Pengembangan Kapasitas Aparatur Desa pada Direktorat Jenderal Bina Pemerintahan Desa, Direktur Pencatatan Sipil pada Direktorat Jenderal Kependudukan dan Pencatatan Sipil, Direktur Fasilitasi Dana Perimbangan dan Pinjaman Daerah pada Direktorat Jenderal Bina Keuangan Daerah, Sekretaris Badan Penelitian dan Pengembangan, Kepala Pusat Pengembangan Kompetensi Kepamongprajaan dan Manajemen Kepemimpinan pada Badan Pengembangan SDM, Kepala Pusat Standarisasi dan Sertifikasi pada Badan Pengembangan SDM, serta Kepala Pusat Pengembangan Kompetensi Pemerintahan Dalam Negeri pada Badan Pengembangan SDM. Meanwhile, JPT Echelon I is Direktur Jenderal Bina Pembangunan Daerah.

Based on the number of registrants and participants from the 2018-2020 JPT open selection, it is known that the highest number of registrants from the Ministry of Home Affairs are men, with a total of 267 registrants. This number is inversely proportional to the number of female registrants, amounting to 45 people. In 2018, there were five female participants from the open selection (out of 34 people). Three people got rank I, but only two people ranked I were appointed in JPT Madya and Pratama, one other ranked I was not selected in JPT Madya (Table 5).

Table.5 Number of registrants and participants from the JPT Open Selection at the Ministry of Home Affairs in 2018-2020

\begin{tabular}{|c|c|c|c|c|c|c|c|c|c|}
\hline \multirow[t]{2}{*}{ Year } & \multirow[t]{2}{*}{ Registrants } & \multicolumn{4}{|c|}{$\begin{array}{c}\text { Registrants of the Ministry of } \\
\text { Home Affairs }\end{array}$} & \multirow{2}{*}{$\begin{array}{c}\text { Registrants } \\
\text { of the } \\
\text { Ministry of } \\
\text { Home } \\
\text { Affairs } \\
\text { (best three) }\end{array}$} & \multicolumn{2}{|c|}{$\begin{array}{l}\text { Selected Female } \\
\text { Participants }\end{array}$} & \multirow{2}{*}{$\begin{array}{c}\text { Female } \\
\text { Participant } \\
\text { s Inducted }\end{array}$} \\
\hline & & Men & $\%$ & Women & $\%$ & & & & \\
\hline 2018 & 136 & 58 & 42,65 & 18 & 13,2 & 34 & 5 & (3 rank I) & 2 \\
\hline 2019 & 104 & 60 & 57,69 & 7 & 6,73 & 23 & 1 & (rank I) & 1 \\
\hline 2020 & 223 & 149 & 66,82 & 20 & 8,97 & 53 & 3 & (2 rank I) & 2 \\
\hline Total & 463 & 267 & & 45 & & 110 & 9 & & 5 \\
\hline
\end{tabular}

Source: Biro Kepegawaian, Kemendagri

\section{Selection}

The implementation of the merit system in filling out JPT through open selection does not mean without obstacles. Therefore, this research is essential to analyze the application of the merit system in the open promotion of JPT for women in the Ministry of Home Affairs and to find out the 
factors that affect the vertical mobility of women in the bureaucracy at the Ministry of Home Affairs.

Several previous studies regarding the merit system and the factors that influence women's vertical mobility in the bureaucracy include: first, a journal (Rakhmawanto et al., 2019) which identifies and analyzes the implementation of the merit system in the JPT Pratama selection process based on (Permenpan RB No 13 Tahun 2014 Tentang Tata Cara Pengisian Jabatan Pimpinan Tinggi Secara Terbuka Di Lingkungan Instansi Pemerintah, 2014); second, the journal (Mius et al., 2019) which analyzes the open selection policy for JPT Pratama in Pekanbaru City using the Edward III Policy Implementation theory and is guided by Permenpanrb Number 13 of 2014; third, the journal (Sunaryo et al., 2019) which analyzes a glass ceiling faced by female leaders to become regional heads in Sragen. These barriers include gender stereotypes, negative campaigns about female leaders, and self-imposed barriers. Fourth, a journal identifies barriers to career development for female civil servants, such as individual, interpersonal, organizational, and family barriers (Krissetyanti, 2018). Each of these barriers consists of artificial and natural barriers.

This research has novelty. Theoretically, to explain the application of the merit system in JPT open promotions uses The Best Person Theory by (Mccourt \& West, 2007) and Selection Process Theory by (Berman, Evan M., Bowman, James S., West, Jonathan P., Van, 2016). Meanwhile, to explain the factors that influence women's vertical mobility in the bureaucracy uses the approach of three theories: Organizational Barriers Theory by (Cross \& Linehan, 2006); Self-imposed Barriers Theory by (Boone et al., 2013); and Gender Role Congruity Theory by (Eagly \& Karau, 2002).

The policy refers to (Peraturan Menteri Pendayagunaan Aparatur Negara Dan Reformasi Birokrasi Nomor 15 Tahun 2019 Tentang Pengisian Jabatan Pimpinan Tinggi Secara Terbuka Dan Kompetitif Di Lingkungan Instansi Pemerintah, 2019), whose implementation has never been measured in the Ministry of Home Affairs. In addition, no research analyzes the application of the merit system in the open promotion of JPT for women at the Ministry of Home Affairs during 20182020. This study will describe the results, conclusions and suggestions in improving the practice of filling in JPT, specifically at the Ministry of Home Affairs and in general in Regional Governments.

\section{RESEARCH METHOD}

The research locus was conducted at the Ministry of Home Affairs. The paradigm or approach used in this research was the postpositivist paradigm. (Creswell, 2009) explained that the postpositivist approach begins with a theory, collects data that supports or refutes that theory, and makes the necessary revisions before additional tests are carried out. In this study, the researchers chose appropriate theories to the research problem and then collected data that supported research using qualitative data collection methods. Qualitative data collection consists of observations, interviews, documents, and audio-visual materials (Creswell, 2009). Qualitative data in this study were obtained through interviews and documents.

Interviews were conducted with informants consisting of: Direktur Fasilitasi Kelembagaan and Kepegawaian Perangkat Daerah pada Direktorat Jenderal Otonomi Daerah; Kepala Sub Bagian Penilaian Kompetensi dan Penataan Jabatan pada Bagian Pengembangan Karier Biro Kepegawaian Sekretariat Jenderal; Kepala Sub Bagian Penilaian Kinerja Pegawai pada Bagian Pengembangan Karier Biro Kepegawaian Sekretariat Jenderal; Guru Besar/Profesor Program Studi Doktor pada Program Pascasarjana Institut Pemerintahan Dalam Negeri; Direktur Sinkronisasi Urusan Pemerintahan Daerah IV pada Direktorat Jenderal Bina Pembangunan Daerah; Direktur Pencatatan Sipil pada Direktorat Jenderal Kependudukan dan Pencatatan Sipil; Direktur Fasilitasi Dana Perimbangan dan Pinjaman Daerah pada Direktorat Jenderal Bina Keuangan Daerah; Sekretaris Badan Penelitian dan Pengembangan; and Kepala Pusat Standarisasi and Sertifikasi pada Badan Pengembangan SDM. Meanwhile, qualitative data were obtained through documents consist of books, seminar papers, journal articles, electronic publications, newspaper articles, institutional records, laws, and regulations, as well as dissertations and theses. 


\section{RESULT AND DICUSSION}

\section{The Best Person for Any Given Job}

The best person concept for a particular job consists of implementing a merit system for work at every level, a list of the best candidates according to qualifications, being open to all employees who meet the qualifications, and a systematic, transparent and competitive process. First, work at each level is a merit principle applied to the recruitment and promotion process based on qualifications, competence, and performance. The filling out of the JPT at the Ministry of Home Affairs is carried out through an open selection according to the provisions stated in Permenpanrb Number 15 of 2019 based on the filling selection procedure, which includes preparation, implementation, and evaluation. At the preparatory stage, planning is carried out regarding the name of the position to be filled, the qualifications and competency standards of each post, the formation of a Selection Committee (Panitia Seleksi), the schedule for the selection process, the selection method, the system used in each selection process, and the concept of announcement of vacancies. Meanwhile, at the implementation stage, the announcement of JPT filling vacancies, the selection process, and the determination of candidate candidates are carried out. Each step in the selection procedure culminates in an evaluation that results in a State Civil Service Commission recommendation as formal evidence that the applicable policies and rules have been carried out filling in the JPT. However, filling in the JPT at the Ministry of Home Affairs has not been fully implemented based on merit criteria according to (Peraturan Menteri Pendayagunaan Aparatur Negara Dan Reformasi Birokrasi Nomor 40 Tahun 2018 Tentang Pedoman Sistem Merit Dalam Manajemen Aparatur Sipil Negara, 2018), because they are still faced with obstacles to succession plans that have not been formalized in the Minister of Home Affairs Regulation.

Second, the best candidate can be proven from the participant who managed to get the highest score and fulfill the requirements in each selection process. It is said that the participant is the most capable among several applicants. The selection process includes the administrative selection and track record tracking; managerial, socio-cultural, and technical competencies; writing papers; and interviews. Each selection process has a weighting composition as the basis for scoring scores, namely $15-20 \%, 20-25 \%, 15-20 \%$, and $30-35 \%$. The best candidates are determined based on aspects of qualifications and competency standards of the position through a selection process that results in value ratings. The Panitia Seleksi then announces the ranking of the results of each selection process to the selected participants. The Panitia Seleksi also conveyed the grades and three names of PPT Pratama and PPT Madya candidates to the Authorized Official (Pejabat yang Berwenang-PyB) and Staffing Officer (Pejabat Pembina Kepegawaian-PPK). PPK, namely, the Minister, chooses one of the three PPT Pratama candidates proposed by PyB. The President chooses one of the three names of PPT Madya candidates based on PPK's considerations. In determining the PPT Madya, the President may be assisted by a team selected by a Presidential Decree. The provisions regarding the determination of the best candidate are regulated in Articles 123 and 124 of (Peraturan Pemerintah Republik Indonesia Nomor 11 Tahun 2017 Tentang Manajemen Pegawai Negeri Sipil, 2017). Although it has been implemented based on applicable legal provisions, the determination of the best candidate is still influenced by political factors.

Third, it is open to all, meaning that the selection for filling in the JPT is available to anyone who meets the requirements, not only from the agency's internal environment or from a limited list of candidates. The JPT filling selection is open to all civil servants who meet the qualification requirements, competency standards, and other requirements needed by the regulations. The selection for filling in the JPT at the Ministry of Home Affairs is carried out openly, starting from the announcement of JPT filling vacancies to the value of each selection process and the ranking of the final results of the entire selection process. The information of JPT filling vacancies are announced through the Circular of the Minister of Home Affairs, which is submitted to all Heads of Agencies at the national level, Governors and Regents/Mayors, and online media seleksiterbuka.kemendagri.go.id. 
Fourth, systematic, transparent, and competitive indicators measure the process of appointing the best candidates due to the selection in a structured manner according to procedures and openly so that the results of recent decisions can be used as input for future decision making. The structured process in selecting filling in the JPT at the Ministry of Home Affairs begins with the announcement of vacancies until the induction of JPT and is open to input on the selection results. Thus, the JPT filling selection can be systematic, transparent, and competitive. It has fulfilled the elements of the JPT filling selection procedure regulated in Permenpanrb Number 15 of 2019. However, JPT filling at the Ministry of Home Affairs has not been fully systematic, transparent, and competitive. There is still a Plt JPT with a term of office exceeding the provisions in (Surat Edaran Kepala Badan Kepegawaian Negara Nomor 1/SE/I/2021 Tentang Kewenangan Pelaksana Harian Dan Pelaksana Tugas Dalam Aspek Kepegawaian, 2021), which is a maximum of three months and can be extended for a maximum of three months so that it can raise the assumption of political dominance in filling out the JPT.

\section{Selection Process in Civil Servant Staffing Process}

The selection process in the civil servant staffing process consists of administrative test selection, screening of candidates with an interview mechanism, checking references and others, negotiating and selecting candidates, and post-selection considerations. First, the administrative test selection assesses the completeness of the required administrative files to separate the eligible participants from those who do not meet the requirements. The details of the administrative files are regulated in Permenpanrb Number 15 of 2019, which consists of: an application letter made by the applicant and stamped; a photocopy of the Decree of The Rank and Position occupied (Surat Keputusan Pangkat dan Jabatan); a photocopy of the latest education diploma following the position applied for; a photocopy of the Tax Notification Letter (Surat Pemberitahunan Pajak); a photocopy of SKP last two years; curriculum vitae; and photocopy of ASN Asset Report (Laporan Harta Kekayaan ASN) or State Administrative Asset Report (Laporan Harta Kekayaan Penyelenggara Negara). There is a difference between the administrative requirements listed in the Ministry of Home Affairs announcement and Permenpanrb Number 15 of 2019. These differences are only for those with the status of civil servants, there are no requirements for SKP last two years, and there are leadership training requirements that are not listed in the Permenpanrb Number 15 of 2019. The strict administrative requirements show a commitment to finding the best candidate who meets the administrative requirements in the first stage. However, it can become an obstacle and give rise to an indication of subjectivity in administrative selection.

Second, screening candidates by interview, reference check, and others is the process of identifying and screening the best candidates through a scoring mechanism or based on the highest ranking. This process is carried out in selecting filling in the Ministry of Home Affairs through competency selection by the Assessor, writing a paper on the vision and mission that will be carried out when occupying the JPT, and interviews. The Panitia Seleksi processes the assessment results based on the weighting of each selection process, announces the ranking of scores, and selects three candidate candidates based on the results of the highest score ranking. In this selection process, there are still obstacles in checking references or tracing track records, where tracking track records is only carried out through an evaluation of curriculum vitae without tracing track records to the place of origin of work, including to superiors, colleagues, and subordinates and other related environments.

The third is negotiating and selecting the names of the best candidates. The negotiation process allows bids to be made to potential candidates to occupy a position, and prospective candidates evaluate the offer. However, (Mius et al., 2019) explained that the selection process is not a two-way but one-way function. The agency has a stronger position to bargain for applicants, and potential candidates can only accept the jobs offered. Meanwhile, the selection process for the best candidates in the JPT filling selection is carried out by the Panitia Seleksi based on consideration of the ranking of the results of each selection process, with the composition of the Panitia Seleksi by the provisions, are $45 \%$ from internal elements and 55\% from external elements. 
Fourth, the last stage in the selection process for selecting the best candidate is based on The Selection Process Theory, namely the consideration of drug test results and medical examinations. In the JPT filling selection at the Ministry of Home Affairs, the interview selection is the last process in the JPT filling selection. The Panitia Seleksi conducts deepening or clarification of applicants regarding the entire selection process. Drug tests and medical examinations are part of the administrative requirements, as evidenced by a physical health certificate, a mental health certificate, and a drug-free certificate. In addition to considering the results of drug tests and medical examinations, the performance evaluation results of the selected candidates are also examined as part of the post-selection consideration process. Based on the results of the study, monitoring and evaluation of performance on PPT are not carried out regularly and continuously according to (Peraturan Pemerintah Nomor 30 Tahun 2019 Tentang Penilaian Kinerja Pegawai Negeri Sipil, 2019), which is at least once every semester, but only based on SKP documents at the end of the year.

\section{Factors Affecting the Vertical Mobility of Women in the Bureaucracy at the Ministry of Home Affairs Organizational Policies}

Barriers originating from the organization include organizational bias policies and attitudes, informal networks supporting promotion, and women's career advancement assistance. First, policies in an organization come from decisions of management or organizational leaders, including policies regarding employee promotions. Organizational policies and attitudes can become barriers or transparent barriers for women in a promotion such as selection for filling JPT, which is not carried out systematically, openly, and competitively, limiting women's opportunities to occupy JPT, subjective criteria that support male candidates and organizational culture that hinders women from taking advantage of family-friendly policies.

The study results indicate no policies and organizational biases hinder women's PPT career development from occupying JPT positions. The selection for filling in the JPT is systematically, openly, and competitively based on clear criteria through an open selection process and is available to announcements and selection results. However, the existence of standards in the selection of filling in the JPT does not mean that there is no leadership discretion or wisdom in determining the best candidate. Coughlan (in Cross \& Linehan, 2006) says that the absence of criteria in selecting for promotion allows for discretion or discretion of the leadership in making subjective decisions. Attitudes and personal views towards women most likely influence this policy. The leadership's preference in decision-making remains even though individual perspectives and opinions towards women do not cause it. The selection for filling in the JPT also does not limit the opportunities for women to register and become the best candidates. And, there are no subjective criteria that support male candidates. The number of female structural officers who meet the rank requirements is not a constraint. The small number of women who register is due to women's lack of interest in participating in the open selection. It is influenced by a reluctance to develop, choices between family and career, lack of family or partner support to establish careers, complicated selection registration requirements, many selection processes, absence of information about the causes of failure in the selection process, and there is no appeal from the agency to women who meet the requirements to participate in the selection.

In addition, women who work have more responsibilities than men because women also have responsibilities as wives and homemakers besides having responsibilities as employees. It refers to Rees' statement (in Cross \& Linehan, 2006) that women have a disproportionate responsibility with men to take care of the household and take care of children, even in situations where husband and wife work. Women still bear the burden of responsibility. However, organizational culture does not prevent women with more responsibilities than men from taking advantage of family-friendly policies according to their needs and regulations.

Second, another organizational barrier is the informal network that supports promotion. (Cross \& Linehan, 2006) said that managerial decisions are made based on the access that a person has to information obtained through formal networks and informal networks. Informal networks 
are vital to senior management levels, such as support, upward mobility, and career advancement. The results showed that four out of five female PPTs in the Ministry of Home Affairs did not have an informal network. Informal networks do not influence promotion decisions to a higher level. Promotion is the result of qualification, competence, and performance. Thus, it is not following the opinion of Burke \& McKeen (in Cross \& Linehan, 2006) that women at the management level lack an internal network within the organization that can influence decisions in employment such as recruitment and promotion. The organizational structure also does not affect women's opportunities to join informal networks. It is also inconsistent with the opinion of Travers \& Pemberton (in Cross \& Linehan, 2006) that the organizational power structure determines access to opportunities to use informal networks.

Third, the last organizational obstacle is assistance in the advancement of women's careers. Two of the three female PPTs at the Ministry of Home Affairs said they did not have a mentor to help develop and direct their careers. Meanwhile, the other three female PPTs have mentors in career development, including husbands, direct leaders, other work units, and employees. The importance of mentors in women's careers as stated by Burke \& McKeen (in Cross \& Linehan, 2006) that mentoring relationships are essential for men and crucial for women. However, mentoring is necessary not because women in upper management face more significant organizational, interpersonal, and individual barriers to career advancement but as encouragement in carrying out their work.

\section{Self-imposed Barriers}

Barriers from women themselves consist of a tug-of-war between family and personal life and women's problems that conflict with women's career development. First, all female PPTs at the Ministry of Home Affairs said that women's responsibilities towards family and work were not obstacles to career development or high positions. Thus, it is not following Brizendine's statement; Reddy (in Boone et al., 2013) that self-inhibition is caused by the push and pull between family and personal problems that occur simultaneously as women's promotion to a higher level. In addition, Fogliasso (in Boone et al., 2013) stated that some women face barriers from stereotypes about their roles at work and home.

Women's career problems can be seen from the age when they get promotions, facilities that help facilitate work, the role of organizations in removing cultural and environmental barriers, assisting leadership development, and monitoring women's career progress. The results showed no age limit for women to get promotions. It is not following Brizendine's opinion (in Boone et al., 2013) that organizations provide promotion time to women who have passed the age forties, so they can increase their time to deal with family matters.

Female PPTs also do not have flexibility in time and work location because it has been regulated. Regulations are (Peraturan Pemerintah Nomor 53 Tahun 2010 Tentang Disiplin Pegawai Negeri Sipil, 2010), (Keputusan Presiden Nomor 68 Tahun 1995 Tentang Hari Kerja Di Lingkungan Lembaga Pemerintah, 1995), and (Peraturan Menteri Dalam Negeri Nomor 132 Tahun 2018 Tentang Tunjangan Kinerja Pegawai Di Kementerian Dalam Negeri, 2018). Those Policies regulate the discipline of civil servants on the days and hours of work of civil servants. Thus, Fogliasso (in Boone et al., 2013) stated that organizations should provide more flexible time and location for women in work, which cannot be justified.

As for the facilities that help facilitate women's work, especially women workers who have children, it is stated in the Regulation. They are (Peraturan Menteri Kesehatan Nomor 15 Tahun 2013 Tentang Tata Cara Penyediaan Fasilitas Khusus Menyusui Dan/Atau Memerah Air Susu Ibu, 2013) and (Peraturan Menteri PPPA Nomor 5 Tahun 2015 Tentang Penyediaan Sarana Kerja Yang Responsif Gender Dan Peduli Anak Di Tempat Kerja, 2015). These policies regulate the obligations of government and private agencies to provide facilities for female workers who have children, including facilities and infrastructure for breastfeeding rooms and child care rooms or childfriendly playrooms. The results showed that several work units at the Ministry of Home Affairs already had an ASI Corner for breastfeeding mothers but did not yet have a daycare room. This 
result follows Fogliasso's opinion (in Boone et al., 2013) that organizations should provide child care services.

The last problem for women's careers is the role of organizations in overcoming cultural and environmental barriers, assisting leadership development, and providing a system that can identify and monitor women's career progress. The results showed that there were no cultural and environmental barriers in women's career development. Agencies even assist women in managing barriers, including leadership development. The Ministry of Home Affairs also does not have a system that identifies explicitly and monitors women's career progress. However, it is not necessary because women have the same abilities as men. Thus, Catalyst (in Boone et al., 2013) found no obstacles to support women's career advancement and gain technical experience to compete for leadership positions. However, organizations need to implement a system that can identify and monitor women's career progress is deemed unnecessary because women have the same opportunities as men based on qualifications, competencies, and performance.

Second, women's problems that conflict with women's career development include unwillingness to change workplace places, concessions or permitted by the spouse in careers and mindsets regarding traditional gender roles. The study results show that there are no barriers that women create themselves that hinder their careers. All-female PPT are willing to change workplaces in the context of mutation and promotion of JPT. This statement contradicts Wynen's opinion (in Sakinah, 2018), saying gender factors affect employee attitudes towards open selection. Women tend not to leave their jobs and places of work compared to men.

PPT women also get support from their families or partners in carrying out their responsibilities at home and in the office. The support is in the form of enthusiasm, material, information, and encouragement for self-actualization. As explained by Cropanzano \& Mitchell (in Alifilahtin Utaminingsih, 2019), social support or assistance to overcome women's obstacles in careers can be in the form of emotional, instrumental, informative support and self-assessment or appreciation.

While the mindset regarding traditional gender roles, men are considered to have no time limit in carrying out work in the office compared to women who have limitations because of their roles as career women, wives, and homemakers. Thus, according to Mavin's statement (in Krissetyanti, 2018), working women must adapt to career development, work patterns, and fulltime careers, which tend to be stereotypes of male workers in the organizational environment. The mindset about traditional gender roles is also considered a view of men's position as husbands who should provide for the family. It answers the statement by Eagly \& Karau (in Sunaryo et al., 2019) that men are associated as leaders while women are not aligned with a leader.

\section{Barriers to prejudice regarding the characteristics of women with leadership role requirements}

The last factor that affects women's vertical mobility is the barriers to prejudice regarding the characteristics of women with the requirements of a leadership role. First, the characteristics of self-promotion, self-confidence, and assertiveness are not only owned and dominated by male leaders, so that leadership abilities are no more a stereotype of men. Thus, (Schuh et al., 2014) mentioned that successful leadership behavior is associated with competitive, assertive, and definite attributes traditionally considering male characteristics, which are the opposite.

Second, attitudes that reflect the characteristics of women, warm and friendly, caring and supportive, complement the attributes of male leaders. Ridgeway (in Eagly \& Karau, 2002) stated that women who try to exert influence in men's groups would be more successful if they were friendly, caring, and supportive. The results of this study are also evidence of the inaccuracy of the theory of gender role conformity (Eagly \& Karau, 2002). Female leaders have a combination of agentic and communal attributes. 
The following is a summary of the conclusions from the analysis of the factors that affect women's vertical mobility in the Ministry of Home Affairs, which are summarized in the (table 6):

Table.6 Factors Affecting the Vertical Mobility of Women in the bureaucracy at the Ministry of Home Affairs

\begin{tabular}{|c|c|c|c|}
\hline Variable & Variable Dimension & Indicator & Research Result \\
\hline \multirow[t]{4}{*}{$\begin{array}{l}\text { Organizational } \\
\text { Barriers (Cross \& } \\
\text { Linehan, 2006) }\end{array}$} & \multirow[t]{2}{*}{$\begin{array}{l}\text { Organizational bias policies } \\
\text { and attitudes }\end{array}$} & $\begin{array}{l}\text { Open selection based on a } \\
\text { fair selection process }\end{array}$ & $\begin{array}{l}\text { The selection for filling in the JPT is } \\
\text { systematically, openly, and competitively } \\
\text { based on clear criteria through an open } \\
\text { selection process and is available to } \\
\text { announcements and selection results. }\end{array}$ \\
\hline & & $\begin{array}{l}\text { Ease of taking advantage of } \\
\text { family-friendly policies }\end{array}$ & $\begin{array}{l}\text { Organizational culture does not prevent } \\
\text { women with more responsibilities than } \\
\text { men from taking advantage of family- } \\
\text { friendly policies according to their needs } \\
\text { and regulations. }\end{array}$ \\
\hline & $\begin{array}{l}\text { Networking that supports } \\
\text { the promotion }\end{array}$ & $\begin{array}{l}\text { Access to information } \\
\text { through informal networks } \\
\text { to upper management } \\
\text { levels }\end{array}$ & $\begin{array}{l}\text { The majority of female PPT do not have an } \\
\text { informal network. Informal networks do } \\
\text { not influence higher-level promotion } \\
\text { decisions because women's vertical } \\
\text { mobility results from qualifications, } \\
\text { competence, and performance. The } \\
\text { organizational structure also does not } \\
\text { affect women's opportunities to join } \\
\text { informal networks. }\end{array}$ \\
\hline & $\begin{array}{l}\text { Mentoring in women's career } \\
\text { advancement }\end{array}$ & $\begin{array}{l}\text { Companion or mentor who } \\
\text { guides to develop a career }\end{array}$ & $\begin{array}{l}\text { Mentoring by husbands, direct leaders, } \\
\text { other leaders, and employees is essential in } \\
\text { advancing women's careers as } \\
\text { encouragement in carrying out work. }\end{array}$ \\
\hline \multirow[t]{4}{*}{$\begin{array}{l}\text { Self-imposed } \\
\text { Barriers (Boone, } \\
\text { Veller, Nikolaeva, } \\
\text { Keith, Kefgen, \& } \\
\text { Houran, 2013) }\end{array}$} & $\begin{array}{l}\text { The tug-of-war between } \\
\text { family and personal life }\end{array}$ & $\begin{array}{l}\text { The push and pull between } \\
\text { family matters and the } \\
\text { promotion of women to } \\
\text { higher levels }\end{array}$ & $\begin{array}{l}\text { Women's responsibilities towards family } \\
\text { and work are not obstacles to developing a } \\
\text { career or occupying a high position } \\
\text { because the agency helps overcome the } \\
\text { barriers in work. }\end{array}$ \\
\hline & \multirow[t]{3}{*}{$\begin{array}{l}\text { Women's problems that } \\
\text { conflict with women's career } \\
\text { development }\end{array}$} & $\begin{array}{l}\text { Unwillingness to change } \\
\text { places of work in the } \\
\text { context of promotion }\end{array}$ & $\begin{array}{l}\text { All-female PPT is willing to change places } \\
\text { of work to transfer and promote JPT. }\end{array}$ \\
\hline & & $\begin{array}{l}\text { Concessions or permitting } \\
\text { by the spouse in careers }\end{array}$ & $\begin{array}{l}\text { All PPT women receive support from their } \\
\text { families or partners in enthusiasm, } \\
\text { materials, information, and } \\
\text { encouragement for self-actualization in } \\
\text { carrying out their responsibilities at home } \\
\text { and work. }\end{array}$ \\
\hline & & $\begin{array}{l}\text { Mindsets regarding } \\
\text { traditional gender roles }\end{array}$ & $\begin{array}{l}\text { The mindset about traditional gender } \\
\text { roles, namely that men do not have a time } \\
\text { limit in carrying out work in the office } \\
\text { compared to women, is not an obstacle. }\end{array}$ \\
\hline \multirow{2}{*}{$\begin{array}{l}\text { Barriers to } \\
\text { prejudice regarding } \\
\text { the characteristics } \\
\text { of women with } \\
\text { leadership role } \\
\text { requirements } \\
\text { (Eagly \& Karau, } \\
\text { 2002) }\end{array}$} & $\begin{array}{l}\text { Prejudice regarding } \\
\text { leadership abilities is more } \\
\text { stereotypical of men (agentic } \\
\text { attributes) }\end{array}$ & $\begin{array}{l}\text { Has a self-promoting, self- } \\
\text { confidence, and assertive }\end{array}$ & $\begin{array}{l}\text { The characteristics of self-promotion, self- } \\
\text { confidence, and assertiveness are not only } \\
\text { owned and dominated by male leaders. }\end{array}$ \\
\hline & $\begin{array}{l}\text { Prejudice regarding the } \\
\text { leadership behavior of } \\
\text { women who are considered } \\
\text { less desirable as leaders } \\
\text { (communal attributes) }\end{array}$ & $\begin{array}{l}\text { Has a friendly, caring, and } \\
\text { supportive }\end{array}$ & $\begin{array}{l}\text { Attitudes that reflect the characteristics of } \\
\text { women, namely warm and friendly, caring } \\
\text { and supportive, complement the attributes } \\
\text { of male leaders. }\end{array}$ \\
\hline
\end{tabular}

Source: processed data

\section{CONCLUSION}

Based on the analysis of the research results, in the application of the merit system in the open promotion of JPT at the Ministry of Home Affairs, The Best Person who occupies the JPT is obtained through an open selection based on the selection procedure as stipulated in Permenpanrb Number 15 of 2019. However, filling in the JPT has not been fully implemented based on merit and systematic, transparent and competitive because it has not implemented a 
succession plan, and there are still JPT Plts with tenures that do not comply with applicable regulations. In The Selection Process, there are differences between the administrative requirements in the Ministry of Home Affairs announcement with Permenpanrb Number 15 of 2019. The track record tracking process is also carried out without going to the applicant's place of origin and monitoring and evaluating PPT performance assessments that were not carried out regularly and continuously. However, the JPT filling selection has been carried out openly for all, from the announcement of JPT filling vacancies to the final score rating of the entire selection process. The selection of the best candidates by the Panitia Seleksi is carried out based on consideration of the value ratings of the results of each selection process.

Regarding the factors that affect the vertical mobility of women in the bureaucracy, there are no barriers either from the organization, self-imposed and prejudices regarding the characteristics of women with the requirements of leadership roles, which hinder women's PPT careers. The selection for filling in the JPT does not limit the opportunities for women to register and become the best candidates. However, the number of women participating in the selection tends to be small due to women's lack of interest in registering.

From the conclusion of the analysis of the application of the merit system in the open promotion of JPT and the factors that affect women's vertical mobility in the Ministry of Home Affairs, several recommendations given to the concept of The Best Person for a particular job, including accelerating the ratification of the succession plan in the Minister of Home Affairs Regulation and enforcing a period of the position of Plt JPT by applicable regulations. While in The Selection Process, adjusting the administrative requirements in the announcement at the Ministry of Home Affairs with Permenpanrb Number 15 of 2019 and conducting a track record tracking process not only based on an evaluation of the curriculum vitae but also the place of origin of the applicant's work. Monitoring and evaluation of PPT performance assessments also do on a regular and ongoing basis at least every six months by comparing the performance agreement and SKP and describing the performance achievements and innovations carried out.

The researcher also provides recommendations to optimize the number of women participating in the JPT filling selection and the productivity of women who have children by inviting female employees who meet the requirements to register for the selection and complete gender-responsive work facilities through childcare facilities. These results also show differences from previous studies. The merit system policy in this study refers to Permenpanrb Number 15 of 2019. In addition, this study shows that there is no glass ceiling that affects the vertical mobility of women's PPT in the bureaucracy. The Theory of Organizational Barriers, Selfimposed Barriers, and Gender Role Congruity are not accurate. However, the number of women who registered for the open selection tends to be small due to women's lack of interest influenced by the self-imposed barrier. Therefore, further research is needed to explore the factors that influence the interest and attitude of employees to participate in the open selection, especially female employees.

\section{ACKNOWLEDGEMENT}

This article was written based on the author's thesis under Prof. Dr. Eko Prasojo, Mag.rer.publ at the University of Indonesia. The author thanks Prof. Dr. Eko Prasojo, Mag.rer.publ, Ministry of Home Affairs, and all informants.

\section{REFERENCE}

Badan Kepegawaian Negara. (2019). Buku Statistik ASN. https://eis.bkn.go.id 
Berman, Evan M., Bowman, James S., West, Jonathan P., Van, M. R. (2016). Human resource management in public service: paradoxes, processes, and problems (5th ed). SAGE Publications, Inc.

Boone, J., Veller, T., Nikolaeva, K., Keith, M., Kefgen, K., \& Houran, J. (2013). Rethinking a Glass Ceiling in the Hospitality Industry. Cornell Hospitality Quarterly, 54(3), 230-239. https://doi.org/10.1177/1938965513492624

Creswell, J. W. (2009). Qualitative, quantitative, and mixed methods approaches. Research Design Qualitative Quantitative and Mixed Methods Approaches. SAGE Publications, Inc.

Cross, C., \& Linehan, M. (2006). Barriers to advancing female careers in the high-tech sector: Empirical evidence from Ireland. Women in Management Review, 21(1), 28-39. https://doi.org/10.1108/09649420610643394

Eagly, A. H., \& Karau, S. J. (2002). Role congruity theory of prejudice toward female leaders. Psychological Review, 109(3), 573-598. https://doi.org/10.1037/0033-295X.109.3.573

Surat Edaran Kepala Badan Kepegawaian Negara Nomor 1/SE/I/2021 tentang Kewenangan Pelaksana Harian dan Pelaksana Tugas dalam Aspek Kepegawaian, (2021).

Krissetyanti, E. P. L. (2018). Women's Perceptions about Glass Ceiling in their Career Development in Local Bureaucracy in Indonesia. Bisnis \& Birokrasi Journal, 25(1). https://doi.org/10.20476/jbb.v25i1.9643

Mccourt, W., \& West, B. S. (2007). Development Economics and Public Policy THE MERIT SYSTEM AND INTEGRITY The merit system and integrity in the public service 1. Public Integrity and Anticorruption in the Public Service, 1-13.

Peraturan Menteri Dalam Negeri Nomor 132 Tahun 2018 tentang Tunjangan Kinerja Pegawai di Kementerian Dalam Negeri, (2018).

Peraturan Menteri Kesehatan Nomor 15 Tahun 2013 tentang Tata Cara Penyediaan Fasilitas Khusus Menyusui Dan/Atau Memerah Air Susu Ibu, (2013).

Peraturan Menteri PPPA Nomor 5 Tahun 2015 tentang Penyediaan Sarana Kerja yang Responsif Gender dan Peduli Anak di Tempat Kerja, (2015).

Permenpan RB No 13 Tahun 2014 tentang Tata Cara Pengisian Jabatan Pimpinan Tinggi Secara terbuka di Lingkungan Instansi Pemerintah, 14 (2014).

Peraturan Menteri Pendayagunaan Aparatur Negara dan Reformasi Birokrasi Nomor 40 Tahun 2018 tentang Pedoman Sistem Merit Dalam Manajemen Aparatur Sipil Negara, (2018).

Peraturan Menteri Pendayagunaan Aparatur Negara dan Reformasi Birokrasi Nomor 15 Tahun 2019 tentang Pengisian Jabatan Pimpinan Tinggi Secara Terbuka dan Kompetitif di Lingkungan Instansi Pemerintah, (2019).

Mius, A., Suradinata, E., Ilham, M., \& Djaenuri, H. M. A. (2019). IMPLEMENTASI KEBIJAKAN SELEKSI TERBUKA DALAM JABATAN PIMPINAN TINGGI PRATAMA DI KOTA PEKANBARU PROVINSI RIAU. Jurnal Kebijakan Pemerintahan, 49-73. https://doi.org/10.33701/jkp.v2i1.917

Prasodjo, E., \& Rudita, L. (2014). Undang-Undang Aparatur Sipil Negara: Membangun Profesionalisme Aparatur Sipil Negara Civil State Apparatuslaw: Building the Professionalism of Civil State Apparatus. Kebijakan Dan Manajemen PNS, 8(1), 13-31.

Prasojo, E. (2009). Reformasi kedua: melanjutkan estafet reformasi. Salemba Humanika.

Keputusan Presiden Nomor 68 Tahun 1995 tentang Hari Kerja di Lingkungan Lembaga Pemerintah, (1995). 
Peraturan Pemerintah Nomor 53 Tahun 2010 tentang Disiplin Pegawai Negeri Sipil, (2010).

Undang-Undang Nomor 5 Tahun 2014 tentang Aparatur Sipil Negara, (2014).

Peraturan Pemerintah Republik Indonesia Nomor 11 Tahun 2017 Tentang Manajemen Pegawai Negeri Sipil, Lembaran Negara 2 (2017).

Peraturan Pemerintah Nomor 30 Tahun 2019 tentang Penilaian Kinerja Pegawai Negeri Sipil, (2019).

Prihartono, S. A. (2019). Analisis Merit System dalam Penempatan Jabatan Penyidik Pembantu di Satuan Reserse Kriminal Polresta Denpasar. Universitas Indonesia.

Rakhmawanto, A., Rusli, B., \& Sintaningrum, S. (2019). Merit System on the Selection Process of the State Civil Apparatus First Senior Executive Service Officials in the Central Java Provincial Government. Jurnal Bina Praja, 21, 31-41. https://doi.org/10.21787/jbp.11.2019.31-41

Sakinah, N. (2018). Employees' Attitude toward the Implementation of Open Selection System for Senior Executive Service Positions. Bisnis \& Birokrasi Journal, 24(1). https://doi.org/10.20476/jbb.v24i1.9469

Schuh, S. C., Hernandez Bark, A. S., Van Quaquebeke, N., Hossiep, R., Frieg, P., \& Van Dick, R. (2014). Gender Differences in Leadership Role Occupancy: The Mediating Role of Power Motivation. Journal of Business Ethics, 120(3), 363-379. https://doi.org/10.1007/s10551-013-1663-9

Sunaryo, S., Sukoco, B. M., Ratmawati, D., \& Ekowati, D. (2019). The Glass Ceiling : Investigating the Dynamics Surrounding the Election of a Female Regent. 20(2), 463-481.

Utaminingsih, A. (2019). Gender dan wanita karir. UB Press. 